\author{
AnNa SOBCZAK \\ Uniwersytet im. Adama Mickiewicza \\ w Poznaniu
}

\title{
IDEOLOGY OF MERITOCRACY IN EDUCATION - SOCIAL RECONSTRUCTIONS OF (IN)EQUALITY
}

\begin{abstract}
Sobczak Anna, Ideology of Meritocracy in Education - Social Reconstructions of (In)equality [Ideologia merytokracji w edukacji - społeczne rekonstrukcje (nie)równości]. Studia Edukacyjne nr 51, 2018, Poznań 2018, pp. 153-163. Adam Mickiewicz University Press. ISSN 1233-6688. DOI: 10.14746/ se.2018.51.8
\end{abstract}

The aim of the article is to reconstruct the theory of meritocracy, according to which each individual has an equal opportunities, regardless of gender, race, and origin, to achieve social and professional success. The author has also attempted to answer the question whether in the current social reality, in which we deal with overeducation and academic diploma inflation, the meritocratic belief about the exclusive influence of individual talents and merits on social and professional success finds its confirmation in social practice. The genesis, essence and directions of criticism of the concept of meritocracy are presented. The article points out that the ideology of meritocracy, despite its egalitarian assumptions, which undoubtedly contributed to the democratization of education, especially at the higher level, confirms social inequalities.

Key words: meritocracy, education, merit, democratization of education, social inequalities

Nowadays in many societies meritocracy is the dominant ideology, which assumes that the social and professional success of individuals depends on their personal skills, education and achievements. Generally speaking, therefore, according to meritocrats, the amount of work during the process of education and then functioning on the labour market determines the occupied social position. Referring to Tomasz Kalbarczyk's words, it can be pointed out that meritocratic rules are the foundation of "standard liberalism", for which the principle that says "talent [and hard work, not social origin - A.S.] is a ticket to career" is important. ${ }^{1}$ An integral part of the ideology of meritocracy is

${ }^{1}$ T. Kalbarczyk, Merytokracja: oligarchia utalentowanych czy sprawiedliwość szans? Studia i Prace Pedagogiczne, 2014, 1, p. 37. 
the conviction of equal opportunities for all people in the struggle for "social awards" (high professional position, high salaries, power, prestige) regardless of gender, race and origin and its guarantor is to be an open education system and fair competition between individuals within its framework.

The postulated equal opportunities and fair competition in turn are to ensure the possibility of "unlimited" social mobility for all individuals, since, as Chris Goode, Lucas A. Keeferb and Ludwin E Molina claim

At the heart of meritocratic ideology is the notion of individual economic mobility, or the ability to gain more economic resources (moving up in social class) than one's ancestors by following the prescriptions for success. By using hard work, effort and talent, any individual in a meritocratic nation should be able to better their social position. ${ }^{2}$

The aim of my articles is to reconstruct the concept of meritocracy and to confront one of its main theses, which says about the unquestionable role of education in fulfilling the idea of equal opportunities with the current social reality. The essence and assumptions of meritocracy will be discussed, as well as the main directions of its criticism. In my article I will also try to answer the question whether in the current situation of social overeducation and academic diploma inflation, the meritocratic belief about the exclusive influence of individual talents and merits on social and professional success finds its confirmation in social practice. In this context, I will refer to the conception of parentocracy, which is said to be increasingly replacing the ideology of meritocracy. However, before I proceed with a detailed discussion of the problem contained in the title, I will present terminological issues of the word "meritocracy".

In the literature there are many examples of definitions (sometimes emphasizing various aspects) of the term "meritocracy", which makes it difficult to describe the unambiguous essence and mechanisms that take place in meritocratic societies. This can be confirmed by the words of Kenneth Paul Tan, who notes that

The concept of meritocracy is unstable as its constituent ideas are potentially contradictory. The egalitarian aspects of meritocracy, for example, can come into conflict with its focus on talent allocation, competition, and reward. In practice, meritocracy is often transformed into an ideology of inequality and elitism. ${ }^{3}$

Therefore, at the beginning of the reflection on the notion of meritocracy, it is worth referring to the sources of its origin. Theorists and researchers de-

${ }^{2}$ C. Goode, L.A. Keefer, L.E. Molina, A Compensatory Control Account of Meritocracy, Journal of Social and Political Psychology, 2014, 2(1), p. 314.

${ }^{3}$ K.P. Tan, Meritocracy and Elitism in a Global City: Ideological Shifts in Singapore, International Political Science Review, 2008, 29(1), p. 7. 
aling with this issue indicate that the term was created thanks to the British sociologist Michael Young in 1958. He used it in his book "The Rise of the Meritocracy, 1870-2033". 4 The newly introduced notion of meritocracy refers to the English word "merit", which the scientist reduced to the following formula: $\mathrm{I}+\mathrm{E}=\mathrm{M}$, where " $\mathrm{I}$ " means intelligence, while " $\mathrm{e}$ " means effort, creating together " $\mathrm{m}$ " which signify "merit". Therefore, according to Michael Young, merit is not only the result of the obtained qualifications, but is also related to the personal abilities of individuals. ${ }^{5}$

It should be noted that Michel Young's work, in which the word "meritocracy" was used for the first time, was in fact a satirical dystopia ${ }^{6}$ depicting the United Kingdom in the years 1870-2033. ${ }^{7}$ More than 40 years after the publication of his book, the author wrote about it in the following way:

The book was a satire meant to be a warning (which needless to say has not been heeded) against what might happen to Britain between 1958 and the imagined final revolt against the meritocracy in $2033 .{ }^{8}$

It describes the ruling elite who, wanted to give the impression of being interested in a fairer society through the use of meritocratic ideals, while at the same time maintaining the current status quo. ${ }^{9}$ Therefore, it should be stressed, referring to Ansgar Allen, that neologism "meritocracy" was created in pejorative sense. The author notes that the creator of this concept claimed in his work that meritocracy would only perpetuate social inequalities and she adds that his predictions partly have proven themselves in reality. ${ }^{10}$ Micheal Young also points out that much of what he described and predicted in his book containing a vision of the future society has already come true. ${ }^{11}$

${ }^{4}$ Cf. i.a. J.J.B. Mijs, The Unfulfillable Promise of Meritocracy: Three Lessons and Their Implications for Justice in Education, Social Justice Research, 2016, 29(1), p.15; A. Liu, Unraveling the myth of meritocracy within the context of US higher education, Higher Education, 2011, 62(4), p. 385.

${ }^{5}$ M. Young, The Rise of the Meritocracy, 1870-2033, London 1958, p. 94, cited in: M. Jackson, Meritocracy, Education and Occupational Attainment: What Do Employers Really See as Merit? Sociology Working Papers, 2001, p. 3.

${ }^{6}$ M. Daunton, Michael Young and Meritocracy, Contemporary British History, 2005, 19(3), p. 285.

${ }^{7}$ M. Young, The Rise of the Meritocracy, cited in: T. Gmerek, Edukacja i nierówności spoteczne, Studium porównawcze na przykładzie Anglii, Hiszpanii i Rosji, Kraków 2011, p. 77.

${ }^{8}$ M. Young, Down with meritocracy, 2001, https://www.theguardian.com/politics/2001/ jun/29/comment [dostęp: 14.01.2019].

9 D. Shifrer, Meritocracy, [in:] Sociology of Education: An A-to-Z Guide, Ed. J. Ainsworth, London 2013, p. 461.

${ }^{10}$ A. Allen, Michael Young's The Rise of the Meritocracy: A Philosophical Critique, British Journal of Educational Studies, 2011, 59(4), p. 367.

${ }^{11}$ M. Young, Down with meritocracy. 
At this point it should be noted that although we owe the creation of the term "meritocracy" to Michael Young and he is often perceived as the one who created the foundations for the emergence of contemporary ideology of meritocracy, in the literature of the subject we can find the information that meritocratic ideas first appeared in ancient times in the works of the Chinese philosopher Confucius. ${ }^{12}$ This is confirmed by Chang-Hee Kim's and Yong-Beom Choi's considerations on the current perception of the theory of meritocracy. The authors list a number of scholars (Bell, 2012; Poocharoen \& Brillantes, 2013; Babcock \& Freivogel, 2015; Yes, 2015; Zhang, 2015) who prove that the principles that have served to create the contemporary concept of meritocracy in Western countries originate in Asia. They also emphasize that it was "an antecedent to the meritocratic practices of Western societies". ${ }^{13}$ In ancient China, the world's first civil service exams were introduced between the 6th and 2nd centuries B.C., which enabled individuals to advance in society on the basis of their merits and not their bloodlines, as has been the case so far. ${ }^{14}$ This initiated the emergence of meritocratic ideas. They were exemplified by a competitive examination system of the civil service called "Keju", which was to be the foundation of meritocratic social selection from that time on. ${ }^{15}$ However, as Ye Liu points out,

The Confuction meritocracy promoted social selection by the Keju, which was used as an ultimate political tool to safeguard the scholar-official class' status and privilege through different successive dynasties and to maintain the imperial Crown's control over divided regional interests over shifting political circumstances. ${ }^{16}$

The author also adds that despite the fact that

social selection through civil service examinations has long been associated with social mobility; (...) it was no more than a sponsored contest with competitive examinations in form and sociocultural reproduction in nature. ${ }^{17}$

The Chinese idea was disseminated in British India in the 17th century, followed by the United States and Europe. ${ }^{18}$ The conception of meritocracy has found at the centre of interest of many scientists, because as Chang-Hee Kim and Yong-Beom Choi note that, in order to understand its inherent components - various social and cultural factors - research on meritocracy has

${ }^{12}$ D. Shifrer, Meritocracy, p. 461.

${ }^{13}$ C.H. Kim, Y.B. Choi, How Meritocracy is Defined Today?: Contemporary Aspects of Meritocracy, Economics and Sociology, 2017, 10(1), p. 112.

${ }^{14}$ D. Shifrer, Meritocracy, p. 461.

${ }_{15}$ Y. Liu, Higher Education, Meritocracy and Inequality in China, Singapore 2016, p. 12.

${ }^{16}$ Ibidem, p. 110.

17 Ibidem, p. 34.

${ }^{18}$ D. Shifrer, Meritocracy, p. 461. 
been carried out in various disciplines, including economics, psychology, education, public administration and many others. ${ }^{19}$

Although there are many works, as has already been mentioned above, devoted to the concept of meritocracy, the authors of which often have conflicting views on its validity and practical application, it seems that it can be generally indicated here that this concept as the rule of merit is defined both in a broader (largo) and narrower (stricto) sense. Kenneth Paul Tan explains that in the former case it concerns

a practice that rewards individual merit with social rank, job positions, higher incomes, or general recognition and prestige. The practice gives all potentially qualified and deserving individuals an equal and fair chance of achieving success on their own merit, which is usually a mixture of effort and talent, both innate and cultivated

as well as in the broad sense may also means merit in the context of the principles influencing the functioning of politics, economy and the entire society of a given country. According to the quoted author, the rule of merit in a narrower sense refers to

a political system that can select or produce the wisest and best to form a government: an "aristocracy of talent". In democratic elections, the people are given the power to decide what counts as "merit" and who possesses it. ${ }^{20}$

Thus, referring to Ansgar Allen, one can say that currently "meritocracy represents a positive ideal against which we measure the justice of our institutions". ${ }^{21}$ It is worth mentioning that it has also begun to be combined with the ideology called "American Dream", as its main assumption, similar as in the concept of meritocracy, is equal opportunities for every individual. The term "American Dream" refers to the United States, which is seen as a "country of possibilities". Everyone who lives in this country, particular attention here shall be paid to immigrants who come to America, has an equal chance for gaining social and professional success, provided that they work hard to achieve it. This conviction is the foundation of the "American Dream" ideology, which assumes that in the United States every person can achieve wealth. ${ }^{22}$ Referring to the words of Lorriz Anne Alvarado, this idea can be described as follows: "In America, the land of opportunity, the »sky is the limit«; you go as far as your individual talents, abilities, and hard work can take you" ${ }^{23}$ The author emphasizes that this happens according

${ }_{19}$ C.H. Kim, Y.B. Choi, How Meritocracy is Defined Today?, p. 113.

${ }^{20}$ K.P. Tan, Meritocracy and Elitism, p. 8.

${ }^{21}$ A. Allen, Michael Young's The Rise of the Meritocracy, p. 1.

22 L.A. Alvarado, Dispelling the Meritocracy Myth: Lessons for Higher Education and Student Affairs Educators, Vermont Connection, 2010, 31, p. 10.

${ }^{23}$ Ibidem, p. 17. 
to the principle, "you get out as much as you put in", which can also be applied to meritocratic assumptions. ${ }^{24}$

At this point it should be noted that the term "meritocracy" is nowadays particularly used to describe modern educational systems in which intellectual values play a key role and which function in knowledge societies characterised by high social mobility. ${ }^{25}$ At the same time it should be pointed out, referring to Tomasz Gmerek that the idea of "meritocratic society" refers to one of the most interesting theoretical conceptions concerning the principles of distribution of social rewards through the education system. The author also stresses that this idea constructs a specific model of social and professional success of young people through education. ${ }^{26}$ According to meritocratic ideals, education, as Zbyszko Melosik points out,

is the simplest and quickest way to the best places on the labour market, the best paid and prestigious positions, (...) it is the main factor of social mobility (sometimes it is even considered a social elevator that wanders from bottom to top, bringing different people - and different numbers of people - to different floors). ${ }^{27}$

Once again, it must be stressed that in a meritocratic approach, there is a belief that the education system is a factor that compensates for inequalities and divisions in society, in such a way as to ensure that all individuals from different classes and social groups have equal chances of achieving success in life..$^{28}$

In sociology, the category of meritocratic society has found its realization in structural functionalism, which assumes that social life consists in the mutual adaptation of complementary elements of the social system in order for the whole system to function efficiently. ${ }^{29}$ These elements, according to the proponents of the functional-structural conception, are social institutions, which perform numerous functions in social systems. ${ }^{30}$ Thus,

24 Ibidem, p. 10.

25 J.H. Goldthrope, Problems of 'meritocracy', [in:] Education, culture, economy, society, Eds. A.H. Halsey, H. Lauder, P. Brown, A.P. Wells, Oxford 1997, p. 663-676, cited in: T. Gmerek, Edukacja i nierówności społeczne, p. 77.

${ }^{26}$ T. Gmerek, Edukacyjne kredencjały i sukces życiowy młodzieży wspótczesnej, [in:] Młodziė̇ wobec niegościnnej przyszłości, Eds. R. Leppert, Z. Melosik., B. Wojtasik, Wrocław 2005, p. 205.

27 Z. Melosik, Uniwersytet i społeczeństwo. Dyskursy wolności, wiedzy i władzy, Kraków 2009, p. 106.

28 T. Gmerek, Edukacyjne kredencjaty, p. 206.

29 R. Meighan, A sociology of educating, London 1986, p. 241 cited in: Z. Melosik, Wspótczesne amerykańskie spory edukacyjne (między socjologią edukacji a pedagogika postmodernistyczną), Poznań 1994, p. 18.

${ }^{30}$ J.H. Ballantine, The sociology of education. A systematic analysis, Englewood Cliffs 1989, p. 8 cited in: Z. Melosik, Współczesne amerykańskie spory, p. 18. 
according to the theory of structural functionalism, the relationship between education and society is a rational adaptation process characterized by the fact that as the demand of a developing society for qualified employees increases, educational systems develop, which provide knowledge and skills to individuals, as well as carry out the selection of the most talented ones. ${ }^{31}$ This theory explains the development and dissemination of education and training, also at the higher level, which was the answer to the formation of a modern society striving for development based on knowledge. According to functional structuralism, education is an important factor of rapid economic growth and development of meritocratic society. This theory also seeks to explain the educational selection/stratification mechanisms, ${ }^{32}$ that is the principles of creating social inequalities through the education system.

Zbyszko Melosik notes that nowadays people perceive education, in which there is a competition for gaining appropriate education and diploma through the eyes of meritocrats, but they are not aware of it. ${ }^{33}$ However, an inseparable element of contemporary educational theory and, as the abovementioned theoretician define it, of "public discourse" and "common sense" has become meritocratic interpretation of the social functions of higher education regardless of certain criticism of title ideology, especially in the context of social stratification. ${ }^{34}$

Proponents of the meritocratic approach believe that educational diplomas fulfil two elementary functions. The first is that "social awards", which include salaries, jobs or prestige, are distributed fairly in accordance with - as they assume - "objectively measured cognitive achievements". However, according to meritocrats, the second function of educational diplomas is related to the fact that they serve as formal evidence of the existence of a group of educated and qualified people, which is a valuable resource in the form of human capital that can be used in the labour market. ${ }^{35}$ In this context the logic of reasoning, as Zbyszko Melosik points out, is as follows:

The essence is to measure the educational achievements of individuals at different levels of the school system, which leads to their successive sorting (and falling out of subsequent groups from this system). ${ }^{36}$

${ }^{31} \mathrm{C}$. Hurn, The limits and possibilities of schooling. An introduction to the sociology of education, Boston 1978, p. 34 cited in: Z. Melosik, Wspótczesne amerykańskie spory, p. 18.

${ }_{32}$ T. Bilton (Ed.), Introductory sociology, p. 308 cited in: Z. Melosik, Wspótczesne amerykańskie spory, p. 29.

${ }_{33}$ Z. Melosik, Uniwersytet i społeczeństwo, p. 105.

${ }^{34}$ Z. Melosik, Edukacja uniwersytecka i procesy stratyfikacji społecznej, Kultura - Społeczeństwo - Edukacja, 2013, 1(3), p. 21.

${ }^{35}$ Z. Melosik, Uniwersytet i społeczeństwo, p. 106.

${ }^{36}$ Ibidem, p. 106. 
An academic diploma, according to the meritocracy theory, is therefore seen as a "ticket" allowing a young person to achieve success in life. As meritocrats are convinced, the "fair distribution" of prestigious jobs and social positions, as well as privileges and power will takes place among the young people who will get it. ${ }^{37}$

The idea of meritocratic society fits well in the theory of human capital, as it is the development of education and the emergence of new educational institutions that enable the improvement of the quality of human capital, is perceived as the main factor in the creation of a more meritocratic society. This approach assumes that professional position will be a resultant of talent and motivation ${ }^{38}$ to undertake broadly understood education, which, as Wojciech Jarecki points out, plays a priority role in the concept of human capital and is a response to the challenges of a rapidly changing contemporary social reality. ${ }^{39}$

Undoubtedly, meritocratic tendencies influenced the processes of democratization of education, especially at the higher level. In recent decades, higher education, and in particular access to it and the nature of education have significantly changed. Gradually, consecutive formal and legal barriers to access to educational institutions were eliminated. In this context, we can even speak of a massification of higher education, which, apart from the increased economic demand for workers with higher education, was also connected with emancipation movements, as well as a broadly understood struggle for equal rights, which is the foundation of meritocratic society.

Over time therefore, education including academic education, began to lose its sponsored character, which, according to Ralph Turner's conception, relies on formal and legal limitations on access to education ${ }^{40}$ and was increasingly in line with the theory of contest mobility. According to the theory, obtaining a high social status and well-paid professions takes place in a process of "open" competition within the education system, ${ }^{41}$ and the chances of success are the same for every child. ${ }^{42}$ This theory is related to the main idea

37 T. Gmerek, Edukacyjne kredencjaty, p. 206.

38 Ch.J. Hurn, The limits and possibilities of schooling. An introduction to the sociology of education, Boston 1985, p. 89-90, cited in: T. Gmerek, Młodzież i dyplom akademicki. Społeczne konstrukcje sukcesu życiowego, [in:] Środowiska uczestnictwa społecznego jednostek, kategorii i grup (doświadczenia socjalizacyjne i biograficzne), Eds. J. Modrzewski, A. Matysiak-Błaszczyk, E. Włodarczyk, Poznań 2018, p. 577-578. p. 33 .

${ }^{39}$ W. Jarecki, Koncepcja kapitału ludzkiego, [in:] Kapitał ludzki w gospodarce, Szczecin 2003,

40 Por. R.H. Turner, Sponsored and contest mobility and the school system, [in:] Readings in the theory of educational system, Ed. E. Hopper, London 1971, p. 74, cited in: Z. Melosik, Wspótczesne amerykańskie spory, p. 23.

41 Ibidem.

42 M. Huberman, Learning, democratizing and deschooling, [in:] Deschooling, Ed. I. Lister, Cambridge 1974, p. 47, cited in: Z. Melosik, Współczesne amerykańskie spory, p. 23. 
of meritocracy, which states that the task of education is to create the initial "conditions for equality", 43 and its popularization has contributed to the dissemination of education at all levels and has caused in a significant increase in the number of people undertaking higher education and those obtaining academic diploma. Nowadays, we can speak of a surplus of university graduates, which has resulted in the emergence of the overeducation phenomenon ${ }^{44}$ and academic diploma inflation, which, as writes. A. P. Marques refers to the "relative depreciation" of one's education. ${ }^{45}$

At this point it should be pointed out that meritocracy is criticised from many perspectives, in particular by proponents of the theory of credentials. It assumes, contrary to how meritocrats perceive education, that the school system recreates social and economic inequalities through unequal access to diplomas for individuals from different social groups. According to the theory of credentialism, it is more difficult for young people from underprivileged social groups to achieve success in life than for those from "success" groups. ${ }^{46}$

An important accusation against the concept of meritocracy is her erroneous, in the opinion of opponents of meritocratic ideology, assumption of a fair distribution of "social rewards" according to the merits of individuals. As Piotr Sztompka notices, "social life is not so simple that one meritocratic principle ensures a fair distribution of wealth" ${ }^{47}$ The author also explains that the most frequent reason for "non-observance" of the abovementioned meritocratic principle is social exclusion, which in this case relies on pushing certain persons or groups away from the "social rewards" regardless of merit, and also nepotism which means excessive granting of social goods to members of one's family. ${ }^{48}$ In this context, it should be also mentioned the current phenomenon of parentocracy, which is increasingly replacing the ideology of meritocracy, because in the current conditions of diploma inflation and overeducation, parents have a greater impact on the social and professional success of their children through their financial resources, network of contacts and life wisdom than an academic diploma. ${ }^{49}$ Today, we are dealing with a fundamental (renewed) increase in the role of social origin in defining the possibilities

${ }^{43}$ T. Gmerek, Edukacyjne kredencjaty, p. 205.

${ }^{44}$ Cf. i.a. K. Ueno, A. Krause, Overeducation, perceived career progress, and work satisfaction in young adulthood, Research in Social Stratification and Mobility, 2018, 55, p. 51.

${ }_{45}$ A.P. Marques, Unequal Itineraries for Graduates: A Typology of Entrance into Labour Market, Academic Journal of Interdisciplinary Studies, 2015, 4 (1S2), p. 21.

46 T. Gmerek, Edukacyjne kredencjaty, p. 207-208.

47 P. Sztompka, Paradoks sprawiedliwości społecznej: równość zasad nierówności, Ruch Prawniczy, Ekonomiczny i Socjologiczny, 2012, 4, p. 247.

48 Ibidem, p. 248.

49 O. Kivinen, Graduate Credentials in a Changing Labour Market, Higher Education in Europe, 1997, 22, 4, p. 452-453; O. Kivinen, P. Ahola, Higher Education as Human Risk Capital, Higher Education, 1999, 38, p. 204 cited in: Z. Melosik, Uniwersytet i społeczeństwo, p. 138. 
of achieving social and professional success by university graduates. During the period of democratization of education, it gradually was losing its importance, while in a situation of overeducation and academic diploma inflation, it starts to play a decisive role again. ${ }^{50}$ Referring to Pierre Bourdie's theory of cultural reproduction, according which the position of individuals in society depends on the capital they possess ${ }^{51}$ it should be noted that middle-class parents have greater economic, social and cultural capital, which enables them to pave the way for their offspring to achieve a high social position through appropriate socialisation, quality education and social connections from the earliest school years, as opposed to the working class parents, which does not have such resources. An another reason emerges from this for frequent criticism of the meritocratic assumption of "equal opportunities" for each individual in achieving social and professional success, which in many cases cannot be fulfilled, as the social origin and capital possessed by the child's family determine the quality of education, as well as to a large extent determine the success of the child during and after the education process.

To sum up, it can be concluded that the ideology of meritocracy, despite its egalitarian assumptions, confirms social inequalities, which result both from the lack of possibility to provide all individuals with equal opportunities at the start of education, as well as equal opportunities to use the obtained diploma on the labour market and achieve success in life. However, it should be clearly emphasized that it played an important role in the processes of democratization of education, thereby increasing access to education for previously discriminated groups (women, people from lower social classes, racial and ethnic minorities). Moreover, it should be noted that all conceptions and theories in the field of sociology of education, and thus also the conception of meritocracy and structural functionalism, regardless of the contradictions between them, explain certain aspects of the functioning of the education system, because as Zbyszko Melosik points out, each of them "provides insight into a different corner of the world of education or sheds a different light on the same corner". ${ }^{52}$

\section{BIBLIOGRAPHY}

Allen A., Michael Young's The Rise of the Meritocracy: A Philosophical Critique, British Journal of Educational Studies, 2011, 59(4).

${ }^{50}$ Z. Melosik, Uniwersytet i społeczeństwo, p. 137-138.

${ }^{51}$ Por. P. Bourdieu, Reprodukcja. Elementy teorii systemu nauczania, Warszawa 2011.

${ }_{52}$ Z. Melosik, Wspótczesna amerykańska socjologia edukacji: kilka uwag o statusie teorii, Forum Oświatowe, 1994, 1(10), p. 45. 
Alvarado L.A., Dispelling the Meritocracy Myth: Lessons for Higher Education and Student Affairs Educators, Vermont Connection, 2010, 31.

Bourdieu P., Reprodukcja. Elementy teorii systemu nauczania, Wydawnictwo Naukowe PWN, Warszawa 2011.

Daunton M., Michael Young and Meritocracy, Contemporary British History, 2005, 19(3).

Gmerek T., Edukacja i nierówności społeczne. Studium porównawcze na przykładzie Anglii, Hiszpanii i Rosji, Wydawnictwo Naukowe Impuls, Kraków 2011.

Gmerek T., Edukacyjne kredencjały i sukces życiowy młodzieży wspótczesnej, [w:] Młodzież wobec niegościnnej przyszłości, Eds. R. Leppert, Z. Melosik., B. Wojtasik, Wydawnictwo Naukowe Dolnośląskiej Szkoły Wyższej Edukacji TWP we Wrocławiu, Wrocław 2005.

Gmerek T., Młodzież i dyplom akademicki. Społeczne konstrukcje sukcesu życiowego [w:] Środowiska uczestnictwa społecznego jednostek, kategorii i grup (doświadczenia socjalizacyjne i biograficzne), Eds. J. Modrzewski, A. Matysiak-Błaszczyk, E. Włodarczyk, Wydawnictwo Naukowe UAM, Poznań 2018.

Goode C., Keefer L.A., Molina L.E., A Compensatory Control Account of Meritocracy, Journal of Social and Political Psychology, 2014, 2(1).

Jackson M., Meritocracy, Education and Occupational Attainment: What Do Employers Really See as Merit? Sociology Working Papers, 2001.

Jarecki W., Koncepcja kapitatu ludzkiego [w:] Kapitał ludzki w gospodarce, Wydawnictwo Uniwersytetu Szczecińskiego, Szczecin 2003.

Kalbarczyk T., Merytokracja: oligarchia utalentowanych czy sprawiedliwość szans? Studia i Prace Pedagogiczne, 2014, 1.

Kim C.H., Choi Y.B., How Meritocracy is Defined Today?: Contemporary Aspects of Meritocracy, Economics and Sociology 2017, 10(1).

Liu A., Unraveling the myth of meritocracy within the context of US higher education, Higher Education, 2011, 62(4).

Liu Y., Higher Education, Meritocracy and Inequality in China, Springer, Singapore 2016.

Marques A.P., Unequal Itineraries for Graduates: A Typology of Entrance into Labour Market, Academic Journal of Interdisciplinary Studies, 2015, 4 (1S2).

Melosik Z., Wspótczesna amerykańska socjologia edukacji: kilka uwag o statusie teorii, Forum Oświatowe, 1994, 1(10).

Melosik Z., Wspótczesne amerykańskie spory edukacyjne (między socjologia edukacji a pedagogika postmodernistyczna), Wydawnictwo Naukowe UAM, Poznań 1994.

Melosik Z., Uniwersytet i społeczeństwo. Dyskursy wolności, wiedzy i władzy, Kraków 2009.

Melosik Z., Edukacja uniwersytecka i procesy stratyfikacji społecznej, Kultura - Społeczeństwo - Edukacja, 2013, 1(3).

Mijs J.J.B., The Unfulfillable Promise of Meritocracy: Three Lessons and Their Implications for Justice in Education, Social Justice Research, 2016, 29(1).

Shifrer D., Meritocracy, [w:] Sociology of Education: An A-to-Z Guide, Ed. J. Ainsworth, Sage, London 2013.

Sztompka P., Paradoks sprawiedliwości społecznej: równość zasad nierówności, Ruch Prawniczy, Ekonomiczny i Socjologiczny 2012, 4.

Tan K.P., Meritocracy and Elitism in a Global City: Ideological Shifts in Singapore, International Political Science Review 2008, 29(1).

Ueno K., Krause A., Overeducation, perceived career progress, and work satisfaction in young adulthood, Research in Social Stratification and Mobility 2018, 55.

Young M., Down with meritocracy, 2001, https://www.theguardian.com/politics/2001/ jun/29/comment [access: 14.01.2019]. 